\title{
Individual differences in activity and habitat selection of juvenile queen conch evaluated using acceleration biologgers
}

\author{
Jacob W. Brownscombe ${ }^{1, *}$, Alexander D. M. Wilson ${ }^{1}$, Emma Samson ${ }^{1}$, \\ Liane Nowell ${ }^{1}$, Steven J. Cooke ${ }^{1}$, Andy J. Danylchuk ${ }^{2}$ \\ ${ }^{1}$ Fish Ecology and Conservation Physiology Laboratory, Ottawa-Carleton Institute for Biology, Carleton University, \\ 1125 Colonel By Dr., Ottawa, ON K1S 5B6, Canada \\ ${ }^{2}$ Department of Environmental Conservation, University of Massachusetts Amherst, Amherst, MA 01003, USA
}

\begin{abstract}
Fine-scale differences in behaviour and habitat use have important ecological implications, but have rarely been examined in marine gastropods. We used tri-axial accelerometer loggers to estimate activity levels and movement patterns of the juvenile queen conch Lobatus gigas $(\mathrm{n}=11)$ in 2 habitat types in Eleuthera, The Bahamas. In 2 manipulations in nearshore areas, queen conchs were equipped with accelerometers and released in adjacent coral rubble or seagrass habitats. Queen conchs were located approximately every $6 \mathrm{~h}$ during daylight by snorkeling, to measure individual differences in linear distance moved, and after $24 \mathrm{~h}$ they were relocated to an alternate habitat ( $24 \mathrm{~h}$ in each habitat). We found significant inter-individual variability in activity levels, but more consistent levels of activity between the 2 habitat types within individual queen conchs. Four (36\%) of the individuals placed in seagrass moved back to the adjacent coral rubble habitat, suggesting selectivity for coral rubble. Individuals showed variable behavioural responses when relocated to the less preferable seagrass habitat, which may be related to differing stress-coping styles. Our results suggest that behavioural variability between individuals may be an important factor driving movement and habitat use in queen conch and, potentially, their susceptibility to human stressors. This study provides evidence of diverse behavioural (activity) patterns and habitat selectivity in a marine gastropod and highlights the utility of accelerometer biologgers for continuously monitoring animal behaviour in the wild.
\end{abstract}

KEY WORDS: Queen conch · Activity · Movement · Accelerometer $\cdot$ Behaviour $\cdot$ Habitat selection

\section{INTRODUCTION}

Animal movement is a central mechanism driving habitat selection, population, and community dynamics (Nathan et al. 2008). It is the result of internal and external stimuli and is commonly aimed at improving foraging opportunities, environmental conditions, avoiding predation, or finding a mate. Movement is limited by the navigational and locomotory capacities of the animal, but even relatively simple

\footnotetext{
*Corresponding author: jakebrownscombe@gmail.com
}

invertebrate species are capable of advanced perception of their environment, resulting in complex patterns of movement and a diversity of behaviours (Matthews 1969, Mather \& Logue 2013). Animal behaviour can be highly flexible, resulting in high variability between individuals even at the population level, but is often consistent within individuals across time and contexts (i.e. personality; Sih et al. 2004, Réale et al. 2007, Bergmüller 2010). The degree and nature of this variability has important implications

() The authors 2015. Open Access under Creative Commons by Attribution Licence. Use, distribution and reproduction are unrestricted. Authors and original publication must be credited. 
for understanding population dynamics, spatial ecology, and how populations will respond to anthropogenic stressors and environmental changes (Wolf \& Weissing 2012). Despite the fact that personality provides important insight into ecological and evolutionary dynamics, it has rarely been examined in invertebrate species, many of which are both ecologically and economically important, as well as being good models for behavioural research (Kralj-Fišer \& Schuett 2014).

The queen conch Lobatus gigas is a large gastropod found throughout the tropical western Atlantic and Caribbean Seas. Highly popular for human consumption and ornamental purposes, it is a socially and economically valuable fisheries resource (Appeldoorn 1994). However, it is currently listed in Appendix II of the Convention on International Trade in Endangered Species (CITES), and concerns are growing that it will be threatened with extinction due to continued exploitation rates throughout its range (Stoner 2003), though it has not yet been formally evaluated for Red List status by the International Union for the Conservation of Nature. Juvenile queen conchs typically occupy shallow (<10 m) nearshore habitats, including coral rubble, seagrass beds, and sand flats (Stoner \& Ray 1993, Glazer \& Berg 1994, Stoner 2003) and often form distinct aggregations that move through nursery habitats foraging on macroalgae, diatoms, and detritus (Stoner \& Waite 1991, Stoner \& Ray 1993). As queen conchs reach sexual maturity ( 3.5 to $4 \mathrm{yr}$; Appeldoorn 1988) they migrate to deeper water habitat (up to $40 \mathrm{~m}$ ), occupying a diversity of substrates. Queen conchs frequently move between substrate types to improve foraging or reproductive opportunities (Stoner \& Sandt 1992). Rates of movement can be surprisingly high (1 to $2+\mathrm{km} \mathrm{yr}^{-1}$ ), with juveniles generally having smaller home ranges $\left(<1000 \mathrm{~m}^{2}\right)$ than adults (2500 to $5000 \mathrm{~m}^{2}$; Hesse 1979). Like most gastropods, queen conch movement is facilitated by a strong foot used to 'crawl' or 'leap' across the substrate (Berg 1975).

While previous studies have provided coarse estimates of queen conch movement over large temporal scales (e.g. Hesse 1979, Stoner \& Sandt 1992), fine-scale activity and movement have never been quantified in the wild. Further, while many studies have examined forms of locomotor activity in gastropods (e.g. Berg 1974, 1975, Perron 1978), individual-level differences in behavioural traits have yet to be quantified in the wild or with respect to environmental factors such as photoperiod or habitat use. Queen conchs occupy a diversity of habi- tats and often exhibit variable preferential habitat use between hard bottoms and seagrass beds across space and time (Randall 1964, Hesse 1979, Stoner \& Sandt 1992, Stoner et al. 1996). Given the importance of movement and habitat use for foraging, survival, and reproduction of queen conch, estimates of behaviour in relation to environmental factors are useful for their conservation (Caro 1999). Recent advances in technology have made such measurements possible (Cooke et al. 2004). Accelerometer biologgers collect sub-second measurements of animal movement and posture that enable quantification of fine-scale behaviour in the wild in a range of species (Shepard et al. 2008, Brown et al. 2013, Brownscombe et al. 2014), including molluscs (Robson et al. 2012). Here, our objective was to examine individual juvenile queen conch activity and movement in the wild across 2 commonly occupied habitat types using tri-axial accelerometer biologgers. We predicted that queen conchs would exhibit diverse behavioural patterns between individuals and across habitat types, with consistent behaviours within individuals across space and time (personality).

\section{MATERIALS AND METHODS}

\section{Study site}

This study was conducted in a shallow embayment of the western Atlantic Ocean in Eleuthera, The Bahamas $\left(24.83981^{\circ} \mathrm{N}, 76.33651^{\circ} \mathrm{W}\right)$. This embayment consisted primarily of seagrass, with adjacent coral rubble substrate 5 to $10 \mathrm{~m}$ in width along the shoreline. The seagrass habitat was predominately (65\% ground cover) turtle grass Thalassia testudinum in sand substrate. The coral rubble habitat consisted primarily of coral debris, but also contained Batophora algae (30\% ground cover). Queen conchs were released $10 \mathrm{~m}$ apart from each other in a linear line adjacent to the shoreline at a mean $( \pm \mathrm{SD})$ depth of $90 \mathrm{~cm}( \pm 3.6)$ in the seagrass and $16 \mathrm{~cm}( \pm 1.6)$ in the coral rubble. Within $8 \mathrm{~m}$ of release locations, habitat consisted of $988 \mathrm{~m}^{2}(71 \%$ of study area) of seagrass and $405 \mathrm{~m}^{2}(29 \%)$ of coral rubble. This study was conducted in the wild; hence, external factors such as the density of untagged queen conchs and the presence of their predators could not be controlled. Initial surveys of the study site via snorkeling found queen conchs in the coral rubble habitat ( 0.1 to $\left.0.2 \mathrm{~m}^{-2}\right)$, but none in the adjacent seagrass habitat. 


\section{Behavioural measures: activity and movement patterns}

Juvenile queen conchs $(n=12$; mean \pm SD: $16.7 \pm$ $2.0 \mathrm{~cm}$ length, no flared shell lip indicative of maturation; Appeldoorn 1988) were collected from coral rubble habitat and fitted with tri-axial accelerometer loggers (Model X8M-3, 500 mAh battery, $15 \mathrm{~g}$ in air, $25 \mathrm{~Hz}$ recording frequency; Gulf Coast Data Concepts), which were fastened with electrical tape to the dorsal surface of the body whorl (Fig. 1). Colouration of the tape was unique to allow individual identification during recapture and displacement trials. Capture and release of tagged queen conchs occurred in 2 trials: on 30 January 2013 at 17:00 h and on 4 February 2013 at 15:00 h ( $n=6$ per release; different individuals for each release). Tagged queen conchs were released into either the coral rubble or adjacent seagrass habitats $(n=3$ per habitat per release). Releases occurred a minimum of $10 \mathrm{~m}$ apart from each other, and the location of release was marked with a flag. Researchers returned to the site approximately every $6 \mathrm{~h}$ during daylight hours to locate (but not disturb) tagged queen conchs and measure the linear distance moved between observations. Upon location, the marker flag was moved to the new location, and subsequent movement distances were measured from that location. After $24 \mathrm{~h}$, queen conchs were relocated to the alternate habitat. After $48 \mathrm{~h}$, accelerometers were removed, and queen conchs were released back into the coral rubble habitat from which they had initially been collected, but outside of the study area so as to avoid reusing the same individuals in the second trial. One individual released in the coral rubble habitat could not be found at the end of the second trial, resulting in the collection of acceleration data from 11 queen conchs.

\section{Data analysis}

Tri-axial accelerometer loggers continuously recorded acceleration $(g=$ $9.8 \mathrm{~m} \mathrm{~s}^{-2}$ ) at $25 \mathrm{~Hz}$ frequency along 3 axes. Total acceleration comprises static (gravity) and dynamic (queen conch movement) acceleration, with maximum values of $\pm 8 \mathrm{~g}$. Dynamic and static acceleration were separated using a smoothing filter with a $2 \mathrm{~s}$ (50 samples) moving window. Dynamic acceleration

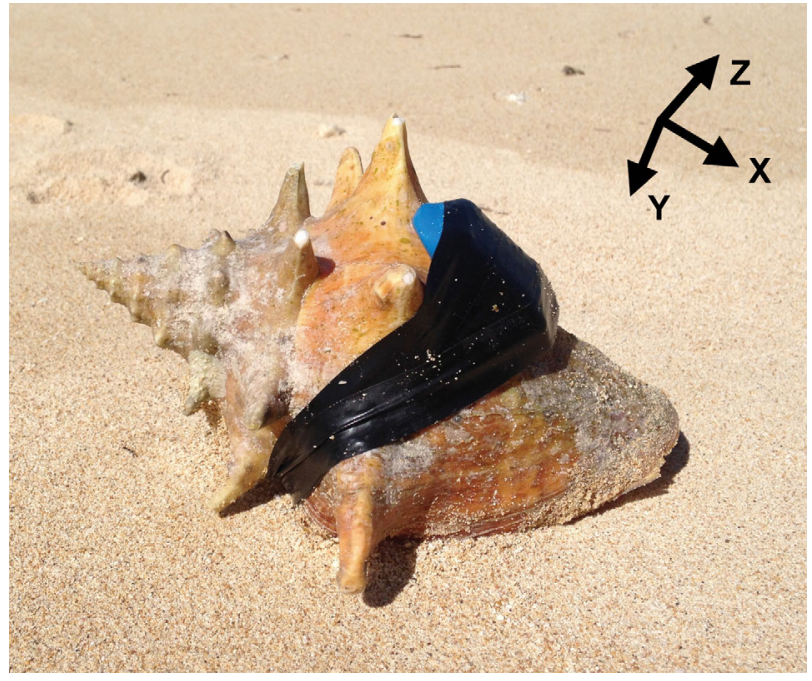

Fig. 1. Queen conch Lobatus gigas tagged with a tri-axial accelerometer

along the $x$-axis (representing the strongest dynamic acceleration signal along the longitudinal axis of the animal; Fig. 1) was analyzed using continuous wavelet transformation with a band-pass filter including frequencies of 0.1 to $2 \mathrm{~Hz}$. A $k$-means clustering algorithm was used to categorize spectra into 6 categories, which were then grouped into either active or inactive behavioural states (Fig. 2). All accelerometer data analyses were conducted with Igor Pro 6.32 software (WaveMetrics) and Ethographer (see Sakamoto et al. 2009).

Queen conch activity levels (\% time active) were analyzed with generalized least squares regression. Queen conch identification (ID), habitat type (coral rubble, seagrass), photoperiod (day, night), and the 2 -way interactions ID $\times$ photoperiod, ID $\times$ habitat, and photoperiod $\times$ habitat were included as predictors. Backward model selection with single-term de-

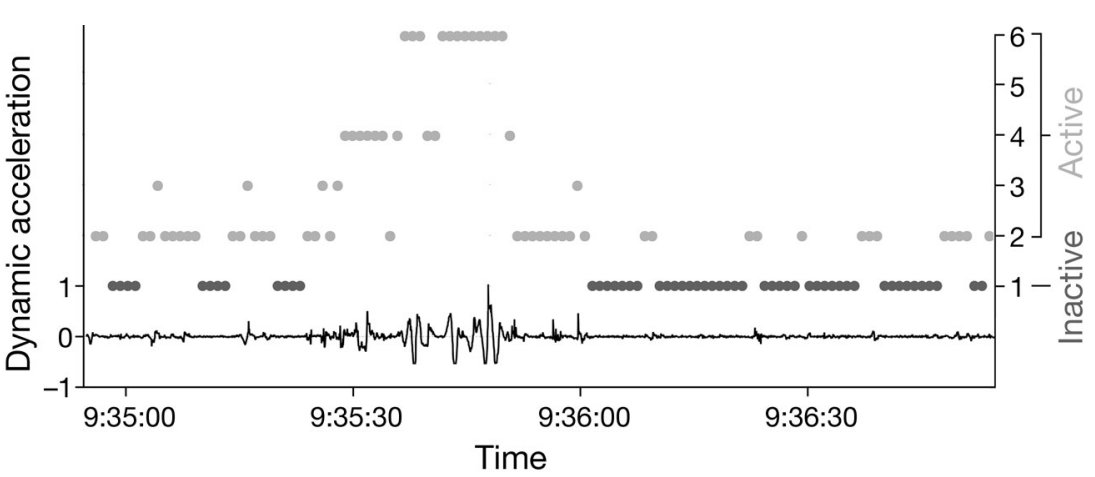

Fig. 2. Dynamic acceleration ( $x$-axis, $g$ ) by a queen conch Lobatus gigas over a 2 min period clustered using a $k$-means algorithm into 6 categories representing active and inactive behavioural states 
letions using log-ratio tests at $\alpha=0.05$ was used to determine the final model, and an autocorrelation structure was implemented to account for autocorrelation within individuals (Pinero \& Bates 2000, Zuur et al. 2009). To examine consistency within individuals, queen conch activity levels were rank transformed and analyzed for concordance between habitat types (coral rubble and seagrass) and between diel periods (night and day) within each habitat type using Kendall's coefficient of concordance $(W)$. Linear distance moved (cumulative sum of linear distances moved between each relocation in meters) by queen conch was analyzed with a linear mixed effects model with time active (h), habitat type (coral rubble or seagrass), and the interaction between time active and habitat type as predictors, and individual queen conch as a random factor. Due to patterns in residuals, linear distance moved was square root transformed. Models were validated using the protocols outlined in Zuur et al. (2009). Habitat selectivity by queen conch was examined by comparing the number of individuals in each habitat type after the $24 \mathrm{~h}$ study periods to the expected number in each habitat based on habitat availability (number of individuals multiplied by percent availability) using a chi-squared test of independence (according to $\mathrm{Neu}$ et al. 1974, León \& Bjorndal 2002). Habitat availability was calculated as the area of each habitat within $8 \mathrm{~m}$ of release locations (mean movement distance by queen conchs during this study). All statistical analyses were conducted using RStudio (Version 0.98.501; R Core Team).

\section{RESULTS}

\section{Activity}

Queen conchs were active an average of $5 \%\left(3 \mathrm{~min}^{-1}\right)$ of the time, and were most active in the late afternoon until midnight, with similar levels of activity in coral rubble and seagrass habitats (Fig. 3). Activity levels were highly variable among individuals, with some more active during daylight hours and others at night (Fig. 4). Individual queen conch and the interaction between individual and time of day were significant predictors of queen conch activity (Table 1). Some individuals were

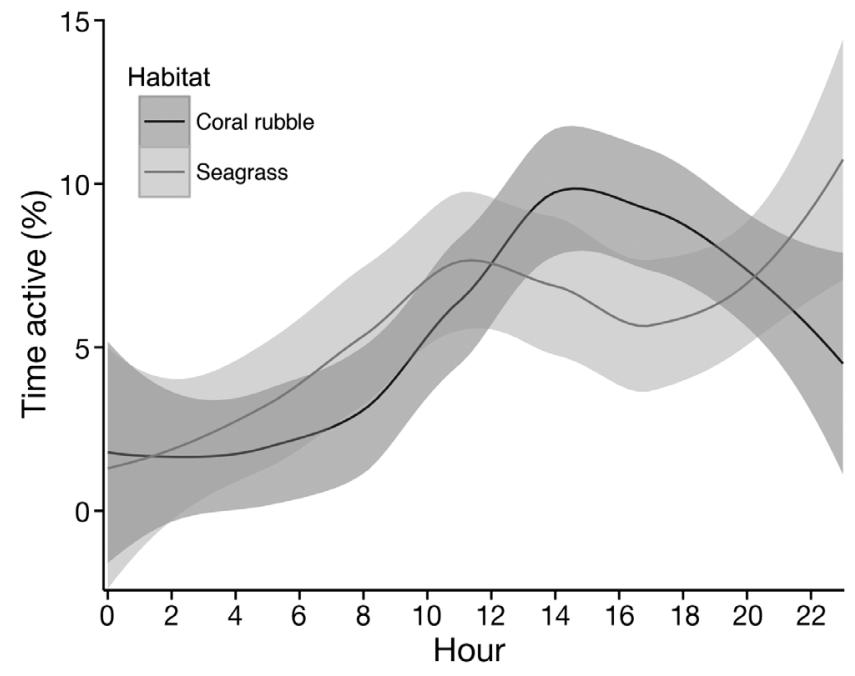

Fig. 3. Time active (\% of total observation time) for queen conchs Lobatus gigas fitted with a Loess smoother by hour of the day in seagrass and coral rubble habitats

Table 1. Significant factors $(\mathrm{p}<0.05$; bold) predicting queen conch (Lobatus gigas) activity levels (\% time active) using generalized least squares estimation. ID: identification number

\begin{tabular}{|lccc|}
\hline Factor & df & F-value & p-value \\
\hline Intercept & 1 & 82.8 & $<\mathbf{0 . 0 0 1}$ \\
Queen conch ID & 10 & 2.9 & $\mathbf{0 . 0 4 6}$ \\
Time of day & 1 & 4.7 & 0.052 \\
Habitat & 1 & 0.2 & 0.68 \\
ID $\times$ Time of day & 10 & 3.0 & $\mathbf{0 . 0 4}$ \\
ID $\times$ Habitat & 10 & 1.5 & 0.27 \\
\hline
\end{tabular}

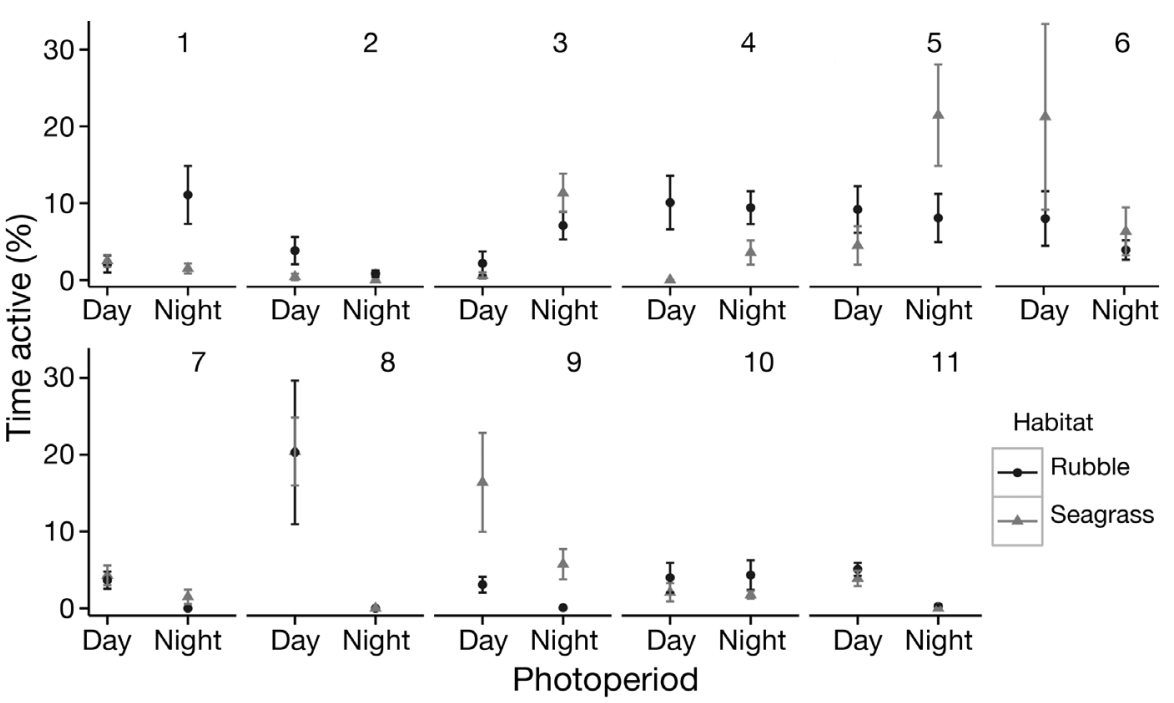

Fig. 4. Lobatus gigas. Mean time active $(\%, \pm \mathrm{SE})$ of individual queen conchs across photoperiods (day and night) in coral rubble (black) and seagrass (grey) habitats. Upper panel shows queen conchs in the first experiment; lower panel shows those in the second experiment 
consistent in their activity levels across diel periods and habitats, ranging from highly active (e.g. Conchs 4 and 5) to less active (e.g. Conchs 2, 7, 11). Some queen conchs became highly active in seagrass habitat compared to coral rubble (e.g. Conchs 5 and 9), while others were the opposite (e.g. Conchs 3 and 6). While there was a high diversity of behavioural patterns, queen conchs did not exhibit consistent levels of activity across habitats (Fig. 5A; $W=0.70, \chi^{2}{ }_{10}=13.9, \mathrm{p}=0.18$ ), or across day and night (Fig. 5B) in either seagrass ( $W=$ $\left.0.50, \chi_{10}^{2}=9.9, \mathrm{p}=0.45\right)$ or coral rubble $(W=0.52$, $\chi_{10}^{2}=10.6, \mathrm{p}=0.39$ ).
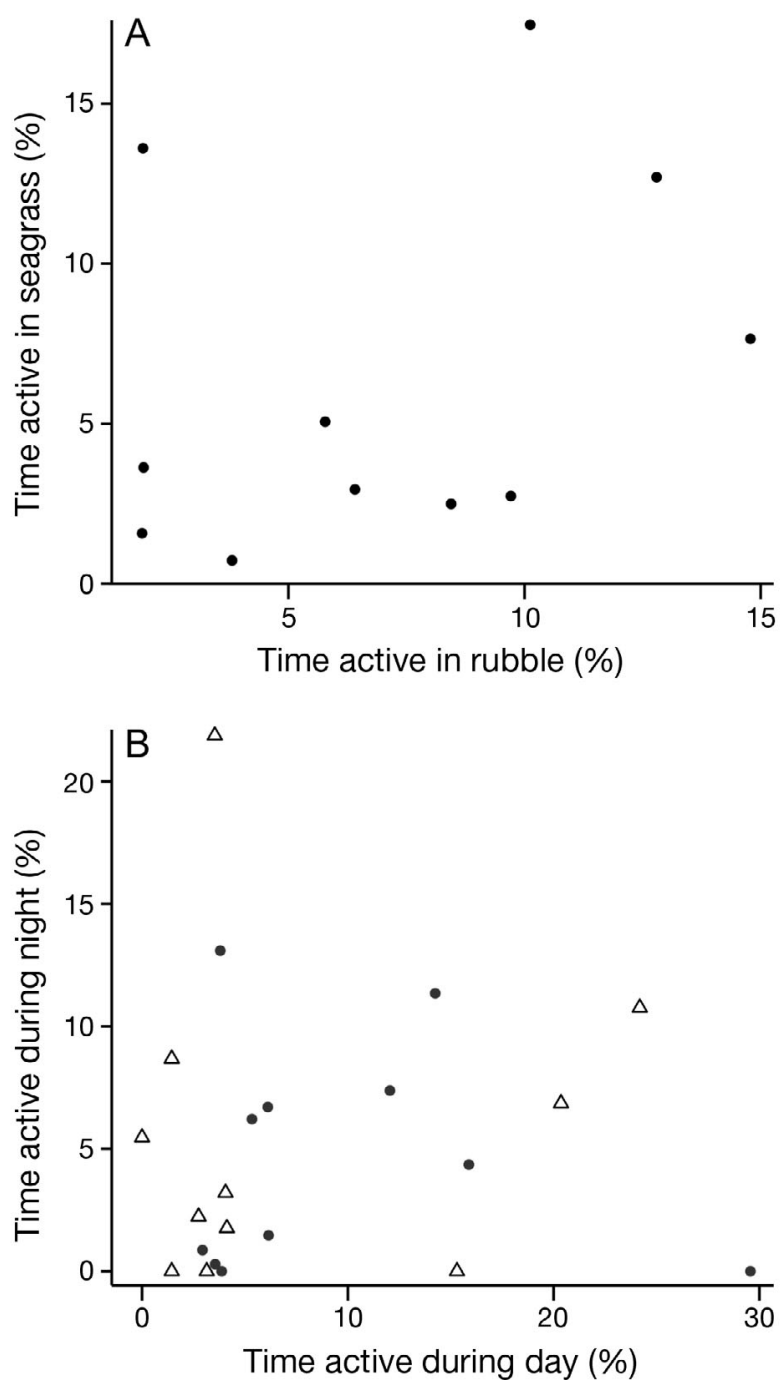

Fig. 5. (A) Relationship between queen conch (Lobatus gigas) activity in coral rubble and seagrass habitats as a \% of total time observed. (B) Relationship between queen conch activity during the day and night in coral rubble $(\Delta)$ and seagrass $(\bullet)$ habitats as a \% of total time observed

\section{Activity and movement}

Queen conchs moved on average $8.7 \mathrm{~m}\left(3.9 \mathrm{~m} \mathrm{~h}^{-1}\right.$ active) in seagrass habitat and $6.6 \mathrm{~m}\left(3.1 \mathrm{~m} \mathrm{~h}^{-1}\right.$ active) in coral rubble over the $24 \mathrm{~h}$ periods (Fig. 6). Linear distance moved generally increased with the amount of time queen conchs were active, and there was a nearly significant effect of activity level on linear distance moved (LME; $t=2.1, \mathrm{p}=0.056$, df $=13$ ), no effect of habitat type $(t=1.3, \mathrm{p}=0.2, \mathrm{df}=13)$, but a significant interaction between time active and habitat type $(t=3.1, \mathrm{p}=0.009, \mathrm{df}=13)$, reflecting a stronger positive relationship between time active and linear distance moved in seagrass habitat than in coral rubble (Fig. 6). Of the queen conchs placed in the seagrass habitat, 4 (36\%) moved back to the coral rubble habitat, while no individuals placed in coral rubble moved to seagrass. After the $24 \mathrm{~h}$ study periods, there was a significant difference in the number of queen conchs in each habitat type compared to the number expected based on habitat availability $\left(\chi^{2}{ }_{1}=\right.$ 5.3, $\mathrm{p}=0.02$ ).

\section{DISCUSSION}

Queen conchs exhibited a high diversity of activity and movement levels among individuals, and across habitat types and diel periods in this study. Interindividual variability within a population was common due to genetic, physiological, and experiential factors; however, individual consistency along key

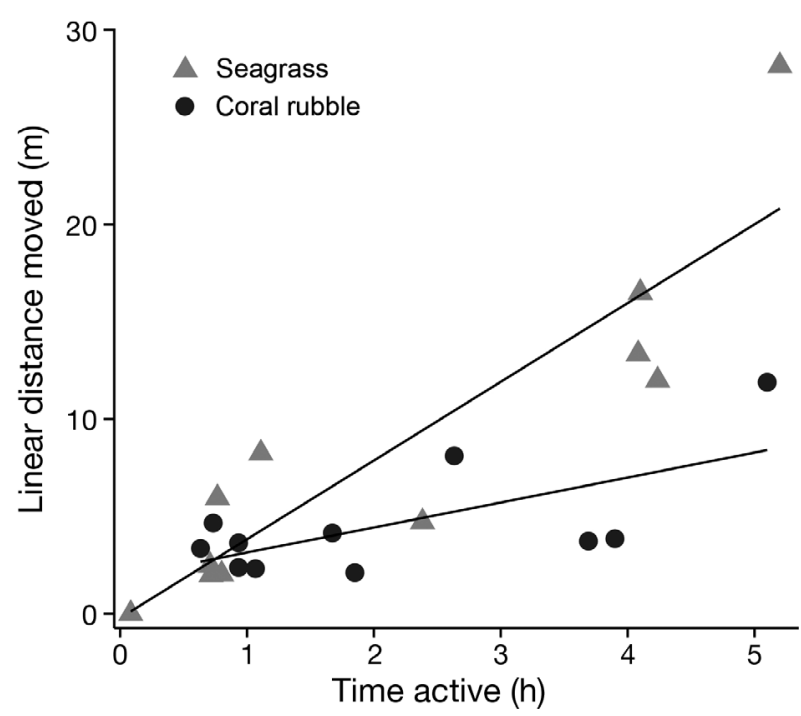

Fig. 6. Cumulative time active (h) and linear distance moved (m) by queen conch Lobatus gigas in seagrass and coral rubble habitats 
behavioural axes (e.g. activity, boldness, aggression) are being documented more and more often both across time and ecological contexts (Sih et al. 2004, Réale et al. 2007, Bell et al. 2009). Indeed, a diversity of behavioural types has been observed not only in vertebrates, but in a few cases also in invertebrates (e.g. Mowles et al. 2012, Mather \& Logue 2013). Locomotory activity is an important behavioural metric that is often correlated with other ecologically relevant traits, including foraging, reproduction, and predator avoidance behaviours (Sih et al. 2004, Dingemanse \& Réale 2005). In this study, we did not find statistically significant consistency in activity levels within individual queen conchs across habitat types or diel periods. However, Kendall's concordance values were relatively high, especially when comparing activity levels between habitats, and a lack of statistical significance may be a symptom of small sample sizes.

In order to further interpret observed queen conch behaviours, it is important to consider that they exhibited selectivity for coral rubble habitat over seagrass in this study. This is not surprising given that queen conchs were collected from coral rubble, while initial surveys of the study site found no queen conch in the seagrass habitat. In many areas of The Caribbean, including The Bahamas, queen conchs have been primarily associated with seagrass habitat (Hesse 1979, Stoner et al. 1996, Stoner 2003); however, some studies have found selectivity for coral rubble as well, areas which often represent important foraging grounds (Randall 1964, Stoner \& Sandt 1992). Here, queen conchs also moved greater distances when placed in seagrass than in coral rubble, and there was a greater positive relationship between activity levels and distance moved. This would suggest that either (1) queen conchs were moving more linearly in seagrass, presumably in search of more preferred coral rubble habitat, or (2) movement was more efficient in seagrass than in coral rubble. Coral rubble is more rugose than seagrass, but dense seagrass would also likely pose challenges for movement, so it is unclear which of the above explanations, or a combination of both, accounts for this pattern. Future research on the energetics of movement through diverse habitat types could provide insight into the space use of this species, especially in the context of the 'energy landscapes' framework (Wilson et al. 2012).

A lack of strong evidence for within-individual consistency in this study does not preclude the existence of behavioural types in this species, especially given the short time period of this study and the chal- lenges posed to these animals. For example, displacing queen conchs to the less preferable seagrass habitat triggered a range of behavioural responses some individuals became more active, many of which were able to return to the coral rubble ( 10 $\mathrm{m}$ away) within $24 \mathrm{~h}$ of displacement, while others responded by becoming relatively inactive (Fig. 4). This could reflect proactive and reactive coping styles (Koolhaas et al. 1999). Proactive individuals tend to be bolder, recover from stress more quickly (i.e. from handling), and explore new environments more readily than reactive individuals (Sih et al. 2004). Similarly, coping styles could influence the response of conch populations to environmental changes or anthropogenic stressors. Highly mobile individuals are more likely to be dispersers and thus play key roles in the colonization of new habitats. These individuals might also be more resilient to environmental change, such as habitat loss and degradation. However, prolonged inconsistent environmental conditions might favour more reactive individuals in the long term (Sih et al. 2004).

Understanding the potential role of behavioural types in queen conch population dynamics and habitat use is an important avenue for future research. For example, queen conchs form distinct foraging aggregations that move through a diversity of substrates, yet Stoner \& Ray (1993) found that they only occupy a small proportion of seemingly suitable habitats. Individual differences in activity might reflect an underlying behavioural mechanism tied to differences in spatial distributions, which are highly dynamic in this species. More active individuals may disperse further and exploit the higher resource availability outside the population core, but, in doing so, they may also experience higher predation risk (Stoner \& Ray 1993). With tradeoffs between higher food availability and higher predation risk at aggregation edges, behavioural types could be tightly linked with the diversity of the life-history characteristics observed in this species (Appeldoorn 1988).

With increasing harvest pressure, reductions in habitat quality and quantity, and declining population numbers, the interest in queen conch population, habitat, and harvest management is increasing (Stoner 2003, Delgado et al. 2004). Here we have demonstrated that queen conchs exhibit a diversity of behavioural patterns, which may have important implications for conservation efforts. For example, Delgado et al. (2004) explored the potential for relocating queen conchs to more suitable habitats when faced with habitat degradation. Behavioural 
responses could influence the success of such initiatives in the long term. For example, more active, bolder individuals could respond better to these types of displacement and might fare better when colonizing new areas.

Queen conchs exhibited significant inter-individual variability in activity levels across habitat types and diel periods. Further, queen conchs showed selectivity for coral rubble habitat (from which they were collected) during this study; relocating them to less preferable seagrass habitat revealed a diversity of behavioural responses which might reflect individual coping styles. This diversity may have important implications for population dynamics and spatial ecology, particularly in the face of increasing anthropogenic and environmental stressors. Given the high variability in behavioural patterns observed in queen conchs in this study, future research should aim at examining the potential of behavioural types in this species, which may have important implications for ecological and evolutionary processes, as well as in situ and ex situ conservation efforts.

Acknowledgements. We thank The Cape Eleuthera Institute for providing field support, and the Bahamian Department of Marine Resources for providing research permits. J.W.B. was supported by the Natural Sciences and Engineering Research Council of Canada (NSERC), and S.J.C. was supported by the Canada Research Chairs Program, Bonefish and Tarpon Trust, and NSERC. A.J.D. was supported by the National Institute of Food \& Agriculture, US Department of Agriculture, and the Massachusetts Agricultural Experiment Station and Department of Environmental Conservation. Thanks to Mackellar Violich for assistance with fieldwork, and Cameron Cooke for first locating conch at the study site which prefaced our research.

\section{LITERATURE CITED}

Appeldoorn RS (1988) Age determination, growth, mortality, and age of first reproduction in adult queen conch, Strombus gigas L., off Puerto Rico. Fish Res 6:363-378

Appeldoorn RS (1994) Queen conch management and research: status, needs and priorities. In: Appledoorn RS, Rodriquez B (eds) Queen conch biology, fisheries and mariculture. Fundacion Científica Los Roques, Caracas, p 301-319

Bell AM, Hankison SJ, Laskowski KL (2009) The repeatability of behaviour: a meta-analysis. Anim Behav 77: 771-783

Berg CJ Jr (1974) A comparative ethological study of strombid gastropods. Behaviour 51:274-322

Berg CJ Jr (1975) Behavior and ecology of conch (superfamily Strombacea) on a deep subtidal algal plain. Bull Mar Sci 25:307-317

Bergmüller R (2010) Animal personality and behavioural syndromes. In: Kappeler P (eds) Animal behaviour: evolution and mechanisms. Springer, Berlin, p 597-621
Brown DD, Kays R, Wikelski M, Wilson R, Klimley AP (2013) Observing the unwatchable through acceleration logging of animal behavior. Anim Biotelem 1:20

Brownscombe JW, Gutowsky LFG, Danylchuk AJ, Cooke SJ (2014) Foraging behaviour and activity of a marine benthivorous fish estimated using tri-axial accelerometer biologgers. Mar Ecol Prog Ser 505:241-251

Caro T (1999) The behaviour-conservation interface. Trends Ecol Evol 14:366-369

Cooke SJ, Hinch SG, Wikelski M, Andrews RD, Kuchel LJ, Wolcott TG, Butler PJ (2004) Biotelemetry: a mechanistic approach to ecology. Trends Ecol Evol 19:334-343

Delgado GA, Bartels CT, Glazer RA, Brown-Peterson NJ, McCarthy KJ (2004) Translocation as a strategy to rehabilitate the queen conch (Strombus gigas) population in the Florida Keys. Fish Bull 102:278-288

Dingemanse NJ, Réale D (2005) Natural selection and animal personality. Behaviour 142:1159-1184

Glazer RA, Berg CJ Jr (1994) Queen conch research in Florida: an overview. In: Appeldoorn RS, Rodriquez B (eds) Queen conch biology, fisheries and mariculture. Fundacion Científica Los Roques, Caracas, p 79-95

Hesse KO (1979) Movement and migration of the queen conch, Strombus gigas, in the Turks and Caicos Islands. Bull Mar Sci 29:303-311

Koolhaas JM, Korte SM, De Boer SF, Van Der Vegt BJ and others (1999) Coping styles in animals: current status in behavior and stress-physiology. Neurosci Biobehav Rev 23:925-935

Kralj-Fišer S, Schuett W (2014) Studying personality variation in invertebrates: why bother? Anim Behav 91:41-52

León YM, Bjorndal KA (2002) Selective feeding in the hawksbill turtle, an important predator in coral reef ecosystems. Mar Ecol Prog Ser 245:249-258

Mather JA, Logue DM (2013) The bold and the spineless: invertebrate personalities. In: Carere C, Maestripieri D (eds) Animal personalities: behavior, physiology, and evolution. The University of Chicago Press, Chicago, IL, p 13-35

Matthews GVT (1969) Navigation in animals. J Navig 22: 118-126

Mowles SL, Cotton PA, Briffa M (2012) Consistent crustaceans: the identification of stable behavioural syndromes in hermit crabs. Behav Ecol Sociobiol 66:1087-1094

Nathan R, Getz WM, Revilla E, Holyoak M, Kadmon R, Saltz D, Smouse PE (2008) A movement ecology paradigm for unifying organismal movement research. Proc Natl Acad Sci USA 105:19052-19059

Neu CW, Byers CR, Peek JM (1974) A technique for analysis of utilization-availability data. J Wildl Manag 38: 541-545

Perron FE (1978) Locomotion and shell-righting behaviour in adult and juvenile Aporrhais occidentalis (Gastropoda: Strombacea). Anim Behav 26:1023-1028

Pinero J, Bates D (2000) Mixed-effects models in S and SPLUS (Statistics and computing). Springer, New York, NY

Randall JE (1964) Contributions to the biology of the queen conch, Strombus gigas. Bull Mar Sci Gulf Caribb 14: 246-295

Réale D, Reader SM, Sol D, McDougall PT, Dingemanse NJ (2007) Integrating animal temperament within ecology and evolution. Biol Rev Camb Philos Soc 82:291-318

Robson AA, Chauvaud L, Wilson RP, Halsey LG (2012) Small actions, big costs: the behavioural energetics of a com- 
mercially important invertebrate. J R Soc Interface 9: 1486-1498

Sakamoto KQ, Sato K, Ishizuka M, Watanuki Y, Takahashi A, Daunt F, Wanless S (2009) Can ethograms be automatically generated using body acceleration data from freeranging birds? PLoS ONE 4:e5379

Shepard ELC, Wilson RP, Quintana F, Gomez Laich A and others (2008) Identification of animal movement patterns using tri-axial accelerometry. Endang Species Res 10: $47-60$

Sih A, Bell A, Johnson JC (2004) Behavioral syndromes: an ecological and evolutionary overview. Trends Ecol Evol 19:372-378

Stoner AW (2003) What constitutes essential nursery habitat for a marine species? A case study of habitat form and function for queen conch. Mar Ecol Prog Ser 257: 275-289

Stoner AW, Ray M (1993) Aggregation dynamics in juvenile queen conch (Strombus gigas): population structure, mortality, growth, and migration. Mar Biol 116:571-582

Editorial responsibility: Brendan Godley,

University of Exeter, Cornwall Campus, UK
Stoner AW, Sandt VJ (1992) Population structure, seasonal movements and feeding of queen conch, Strombus gigas, in deep-water habitats of the Bahamas. Bull Mar Sci 51: 287-300

Stoner AW, Waite JM (1991) Trophic biology of Strombus gigas in nursery habitats: diets and primary food sources in seagrass meadows. J Molluscan Stud 57:451-460

Stoner AW, Pitts PA, Armstrong RA (1996) The interaction of physical and biological factors in the large-scale distribution of juvenile queen conch in seagrass meadows. Bull Mar Sci 58:217-233

Wilson RP, Quintana F, Hobson VJ (2012) Construction of energy landscapes can clarify the movement and distribution of foraging animals. Proc R Soc B 279:975-980

Wolf M, Weissing FJ (2012) Animal personalities: consequences for ecology and evolution. Trends Ecol Evol 27: 452-461

Zuur AF, Ieno EN, Walker N, Saveliev AA, Smith GM (2009) Mixed effects models and extensions in ecology with R. Springer, New York, NY

Submitted: June 10, 2014; Accepted: December 20, 2014 Proofs received from author(s): March 19, 2015 